\title{
Walk the Talk: Bringing Spirituality to Workplace through Transformational Leadership and Emotional Intelligence in Higher Education Institutions
}

(Bercakap Serupa Bikin: Membawa Kerohanian ke Tempat Kerja melalui Transformasi Kepimpinan dan Kecerdasan Emosi di Institusi Pengajian Tinggi)

\author{
Nauman Majeed \\ (Faculty of Business \& Accountancy, University of Malaya) \\ Samia Jamshed \\ (Faculty of Business \& Management Sciences, Superior University) \\ Mohammad Nazri \\ Norizah Mohd Mustamil \\ (Faculty of Business \& Accountancy, University of Malaya)
}

\begin{abstract}
Leadership stayed at the pinnacle in the arena of organizational behavior research since decades and attained significant consideration of scholars pursuing to define multifaceted dynamics of leadership and their influence on spirit at work. Studying workplace spirituality in academicians has a high value that definitely requires attention. This study attempts to explore association amongst transformational leadership and workplace spirituality of academicians through the lens of emotional intelligence in public sector universities of Pakistan. In this study, the hypothesized model was measured by using Structural Equation Modelling - Partial Least Squares. The response from 252 academicians specified that link between transformational leadership and workplace spirituality is statistically noteworthy where emotional intelligence plays a significant role as mediator. The findings enhance positive effects of transformational leadership style consistent with workplace spirituality contributing significantly to leadership literature in the higher education sector and suggest that institutions may implement practices that help in building the environment of workplace spirituality.
\end{abstract}

Keywords: Emotional intelligence; transformational leadership; workplace spirituality; higher education institutions; mediation.

ABSTRAK

Kepimpinan berada di puncak dalam arena penyelidikan tingkah laku organisasi sejak beberapa dekad dan mencapai pertimbangan yang signifikan oleh para sarjana yang mengejar dinamika kepemimpinan beragam dan pengaruhnya pada semangat di tempat kerja. Mempelajari kerohanian di tempat kerja ahli akademik mempunyai nilai tinggi yang pasti memerlukan perhatian. Kajian ini cuba untuk meneroka persaingan antara kepimpinan transformasi dan kerohanian tempat kerja ahli akademik melalui lensa kecerdasan emosi di universiti sektor awam Pakistan. Dalam kajian ini, model hipotesis diukur dengan menggunakan Model Persamaan Struktur - Sebilangan Besar Kuadrat. Respon balas daripada 252 ahli akademik menyatakan bahawa hubungan antara kepimpinan transformasi dan kerohanian di tempat kerja secara statistik perlu diperhatikan di mana kecerdasan emosi memainkan peranan penting sebagai pengantara. Penemuan ini meningkatkan kesan positif gaya kepimpinan transformasi selaras dengan kerohanian tempat kerja yang menyumbang 
dengan ketara kepada kesusasteraan kepimpinan dalam sektor pendidikan tinggi dan mencadangkan agar institusi boleh melaksanakan amalan yang membantu dalam membina persekitaran kerohanian di tempat kerja.

Kata kunci: Kecerdasan emosi; kepimpinan transformasional; kerohanian tempat kerja; institusi pengajian tinggi; pengantaraan

\section{INTRODUCTION}

The significance of growing responsibility, endless high-tech enhancements, adjustments in working life and increasing accountability require leaders of higher education to respond novel. The higher education institutions during the past three decades have been changing and moving away from the traditional bureaucratic archetype towards a more managerial one (Bruckmann \& Carvalho 2018). Universities through education, research, and community involvement play a central role in addressing global environmental challenges and have both multiple and multiplier effects on society (Ralph \& Stubbs 2014). In recent times the concept of transformational leadership is receiving growing attention. The impression that transformational leadership theory may be valuable in higher education institutions is supported by a meta-analytic review (Balwant 2016). Transformational leadership behaviors appear to upkeep team learning via stimulating spirit at work and team efficacy (KoeslagKreunen et al. 2018). As the higher education institutions have become increasingly concerned with key performance indicator KPI - led planning and strategy, therefore it is imperative that the leaders of higher educational institutions walk the talk, share responsibility with formal and informal leaders from faculty and staff group and practice what they preach through transformational leadership behavior. It is an old but ongoing debate, the leadership style debate, which matters the most, put roughly, who leads or where and how to lead (Breakwell \&Tytherleigh 2010). The higher education institutions during the past three decades have been changing and moving away from the traditional bureaucratic archetype towards a more managerial one (Bruckmann \& Carvalho 2018). Higher education is no longer a luxury: it is essential to national social and economic development. The concerns facing higher education are multi-dimensional that are not simple and require sophisticated planning, execution, and evaluation. The style of leadership displayed by the head of the department is a vital element which may affect the spirit de corps of instructors significantly. Universities have traditionally provided little or no training for leadership and management positions which are widely regarded as jobs to be avoided or accepted out of a sense of obligation for a defined period, perhaps three years, then passed on to a colleague. Universities' increasing need for skilled leadership and management at various levels implies a requirement for a greater degree of continuity. Consequently, the need for leadership and more professional management is greater than ever.

Pakistan's public and private sector institutions are facing acute challenges in the meaningfulness of workplaces, job satisfaction, and motivation (Ramlall 2004). Organizations are lacking in the spirituality of employees and in providing a meaningful work environment to its human resources that results in high turnover intentions and inadequate organizational performance. Special attention and care are required with respect to academician's engagement and their spirit at work. In the higher education sector, Pakistan has exhibited considerable progress in recent years. The higher education in Pakistan has its peculiar complexities that entail a range of issues and challenges when governing a university, especially in the public sector. Pakistan's higher education sector is predominantly public in nature, with the bulk of research conducted in public universities. 
According to Giacalone and Jurkiewicz (2003), leadership style can play a proactive role in making workplaces more significant spiritually. The literature review uncovers that various updates have been attempted with respect to the association between transformational leadership and other organizational practices. Earlier studies (Cavazotte, Moreno \& Hickmann 2012; Irshad \& Hashmi 2014; Top, Akdere \& Tarcan 2015; Majeed, Nor \& Mustamil 2017) argued that transformational leadership greatly impacts the behavior of subordinates in a positive manner. Nevertheless, there are very limited investigations that survey the connection between transformational leadership and workplace spirituality utilizing mediation model. This study proposes emotional intelligence as a mediator. The idea of workplace spirituality has received rare consideration in the working environment (McKee et al. 2011). Consolidating religiousness along with spirituality in the work setting impacts the fulfillment of job satisfaction with regards to employees to an impressive degree (Porshariati, Dousti \& Moosavi 2014). Transformational leaders help the organizational members by increasing the feeling of importance and making work more meaningful which in turn inspires them to perform above their assigned roles. In building a conceptual framework associating transformational leadership and workplace spirituality the authors' additionally delineated literature of EI that may clarify a reasonable linkage between transformational leadership and workplace spirituality.

Academic views have backed that EI makes a vibrant contribution to workplace spirituality behavior by definitely impacting higher-order spiritual needs of an employee, however, empirical evidence of such an influence is scarce (Crossman 2011). While looking into the existing research patterns in Pakistan's higher education on the subject of leadership and workplace spirituality, it was realized that researchers have addressed the general relationship between organizational outcomes and leadership styles. In-depth understanding of how transformational leadership style is connected to spirituality at the workplace is missing in observational research. The key impetus of this investigation is to provide an empirical proof that practices displayed by transformational leaders can contribute emphatically to academicians' spirit at work and furthermore to broaden orthodox research on transformational leadership and its effect on workplace spirituality.

\section{LITERATURE REVIEW}

\section{TRANSFORMATIONAL LEADERSHIP}

Researchers are becoming increasingly interested in the dominant paradigm approach to transformational leadership in the context of higher education institutions (Balwant, Stephan \& Birdi 2014). Leadership is exercised in complex, dynamic and changing social systems. A stronger emphasis on 'leadership learning' should deliver both better science and better outcomes for leaders in higher education (Middlehurst 2008). The theory of transformational leadership argues that leader practices can empower workers to take an interest in performing extra-role behavior with zeal and enthusiasm. The essence of the transformational leadership is that "these pioneers lift standard individuals to phenomenal statures and perform past the level of desires" (Bass 1985). Transformational leadership not just has turned into a predominant initiative style in the course of recent decades but on the other hand, is considered as a novel worldview approach in leadership research (Majeed et al. 2017). During the period from 2000 to 2012, 752 articles published in 10 top academic journals were reviewed by Dinh, Lord, Gardner et al. (2014) mentioning that without doubt transformational leadership is found to be the highest research field of leadership. Avolio, Waldman and Einstein (1988) identified four classic behaviors of transformational leadership: (1) idealized influence, (2) inspirational 
motivation,(3) intellectual stimulation, and (4) individualized consideration often mentioned as four "I"s.

Individual consideration is the amount of attention a leader pays to his follower on an individual basis and tends to their needs and maintains a two-way communication (Avolio \& Bass 2002). Idealized influence leader becomes a role model and is well-liked and esteemed by his supporters, builds trust and gains legitimacy in the eyes of follower through ethical and moral conduct. Consistent delivery of promises and commitments is necessary for transformational leadership. Charismatic transformational leader delivers on promises and model values that are critical to behavioral integrity. Thus, transformational leaders practice what they preach or in other words, they walk the talk.

Transformational leader exercises intellectual stimulation by inspiring his followers to be innovative and question the status quo with no fear of criticism while encouraging creativity and openness (Avolio \& Bass 2002). The intellectually stimulating leader uses his problemsolving skills to reach decisions and exhibit consensus between leaders and followers. Leaders demonstrate inspirational motivation when they show enthusiasm, communication of high standards and encouragement and a complete vision of the future (Bass \& Riggio 2006). Inspirational leader arouses optimism, enables them to make sense out of their work and challenge them for performance, and demonstrate his commitment to shared vision and goals.

\section{EMOTIONAL INTELLIGENCE}

Emotional Intelligence (EI) supports the idea that admiring of human emotions and relations may lead to the likelihood of handling them more wisely (Weisinger \& Cali 2000). A review of recent research demonstrates a steady increase over the last 10 years in articles which make explicit reference to emotion in higher education. However, further investigation reveals that a very small number of these deal with universities as workplaces (Woods 2010). As research advanced in the field of organizational behavior, EI became a prevalent research subject. Salovey and Mayer (1990) described, EI as "the ability to monitor one's own feelings and emotions, to discriminate among them and to use this information to guide one's thinking and actions". Goleman explained EI in a more understandable, logical and pertinent manner that has been extensively recognized and embraced by scholars and academicians alike. Goleman (1998) suggested EI as a skill that allows a person to recognize, comprehend and display human emotions in the utmost beneficial way as a process to attain positive results by managing one's own behavior and others.

Employees working in service professions like academicians, management, and marketing have evidenced their effectiveness by displaying great intensities of intrapersonal intelligence. Keeping in view the success of an academician in managing changes in higher education settings emotional intelligence is a vital constituent. Therefore, the importance of EI for an academician is unquestionable (Majeed et al. 2017). As teaching career is recognized as one of the central profession (Ishak, Iskandar \& Ramli 2010), for academicians; EI could exhibit to be a dynamic feature of individual's nature and personality. Leaders possessing emotional intelligence skills creates emotional realization and sense of responsibility among workers which enables them to respond positively to diverse situations (Jamshed, Nor \& Bakar 2017). By implementing EI skills, academicians could effectively manage the pressure of the profession, comprehend the social cues and better improve their personal domain. 


\section{WORKPLACE SPIRITUALITY}

Workplace spirituality as one of the novel concepts stands out among the most critical assignments confronted by contemporary social orders in the third millennium (Porshariati, Dousti \& Moosavi 2014, Joelle \& Coelho 2017). It prompts representatives and impels employees to recognize the significance of their work. It adjusts the convictions of the individual to the values of the institutions. With the increasing spiritual talk and research in this field, a debatable matter arises which is to determine the extent of application and practicing these concepts in organizations with true commitment and as the true spirit of spirituality (Majeed 2018).

According to Mousa and Alas (2016), corporate spirituality is a genuineness in the business world that cannot be overlooked. Constructing the spiritual existence of values and morals at the workplace through fondness, affection, and care is crucial for the inner satisfaction of employees. Workplace spirituality urges employees to perceive the possible importance of their work (Majeed et al. 2017). The workplace spirituality is defined from an individual as well as organizational perspective. The organizational perspective defines it as a structure of organizational values embedded in the culture, which encourages the employees' understanding of greatness by work procedures, assists their connection with others providing them a sentiment of joy and completeness (Giacalone \& Jurkiewicz 2003). Workplace spirituality, from an individual's viewpoint, requires finding purpose and objective in life, establishing relationships with others and to align with values of organizations (Mitroff \& Denton 1999).

A wide and complete meaning of workplace spirituality might be difficult to construct since it is associated with hierarchical esteems, organizational values and culture (Pirkola, Rantakokko \& Suhonen 2016). Roof (2015) defines workplace spirituality as: "the divine that informs an individual's existence and shapes their meaning, purpose, and mission in daily lives". Workplace spirituality adjusts the convictions of the individual to the estimations and values of the organization. Employees who are enthusiastic about as well as animated by their work in this way discovering importance and reason in their work (Majeed et al. 2017). As per McKee et al. (2011), there are three essentials of workplace spirituality: meaningfulness of work, sense of community, and aligning of values.

\section{RELATIONSHIP BETWEEN THE CONSTRUCTS}

Transformational leadership and its association with workplace spirituality have extraordinary embellishments on the employees and the hierarchical environment. Leadership skills and emotional intelligence empower organizations in gaining a competitive edge (Jamshed \& Majeed 2019). The connection between corporate spirituality and transformational leadership has elevated a novel lineage of leadership. The nexus of transformational leadership and spirituality has produced a fresh pedigree of leadership. This leadership incorporates the multifaceted unity of stimulation, reassurance, genuineness, ethics, relationship building, inspiration, honesty, and the rejuvenation of spirit (Fairholm 1997). However, presently there is inadequate research to authenticate claims of a linkage between transformational leadership and workplace spirituality. Despite the greater admiration of workplace spirituality, little research is seen to determine and find out which factors can be possible as well as potential causes of workplace spirituality. Collectively quite a few research studies confirm the argument of the positive association between transformational leadership and EI contributing to job performance. Moqbel, Charoensukmongkol and Bakay (2013) claimed that employees' EI can be thought of as a vital feature that grants employees to establish an excellent working environment in their institutions. The outcomes from their study propose that employee EI has a significant linkage amongst the three dimensions of workplace spirituality. Wong and Law 
(2002) contended at the point when workers encounter positive assumptions, they can develop positive affection towards their work atmosphere and the institution. By expounding following hypothesized relationships the study explicitly extends the literature. Based on the above discussion following hypotheses are proposed:

$\mathrm{H}_{1}$ Transformational leadership has a significant positive association with workplace spirituality.

$\mathrm{H}_{2}$ Transformational Leadership has a significant positive association with emotional intelligence.

$\mathrm{H}_{3}$ Emotional intelligence has a significant positive association with workplace spirituality.

$\mathrm{H}_{4}$ Emotional intelligence mediates the relationship between transformational leadership and workplace spirituality.

\section{THEORETICAL FRAMEWORK}

After carefully selecting the constructs a theoretical model is identified for developing the research model and examining the causal relationship between variables. As shown in figure 1 transformational leadership theory is identified to establish the relationships between variables. Transformational leadership theory has gained the attention of numerous scientists in the field of leadership in the course of recent periods. Based on the evidence and hypothesis, the reasonable structure of a theoretical model is built up. The independent variable transformational leadership uses Bass and Avolio (1993) structure consists of dimensions: (1)idealized influence, (2) inspirational motivation,(3) intellectual stimulation, and (4) individualized consideration. The criterion variable is workplace spirituality amongst academicians in higher education organizations of Pakistan. Since workplace spirituality is fundamental in the educational institutions, this examination is intended to quantify and measure workplace spirituality and to survey how spirit at the workplace is related to transformational leadership. The mediating variable is EI that consists of the dimensional structure by Wong and Law (2002) for assessing emotional intelligence. (1) Self-emotion appraisal, (2) others emotion appraisal, (3) understanding others emotions and (4) regulation of emotions. The linkage between emotional intelligence and workplace spirituality is the one important area with incredible potential in the field of organizational sciences.

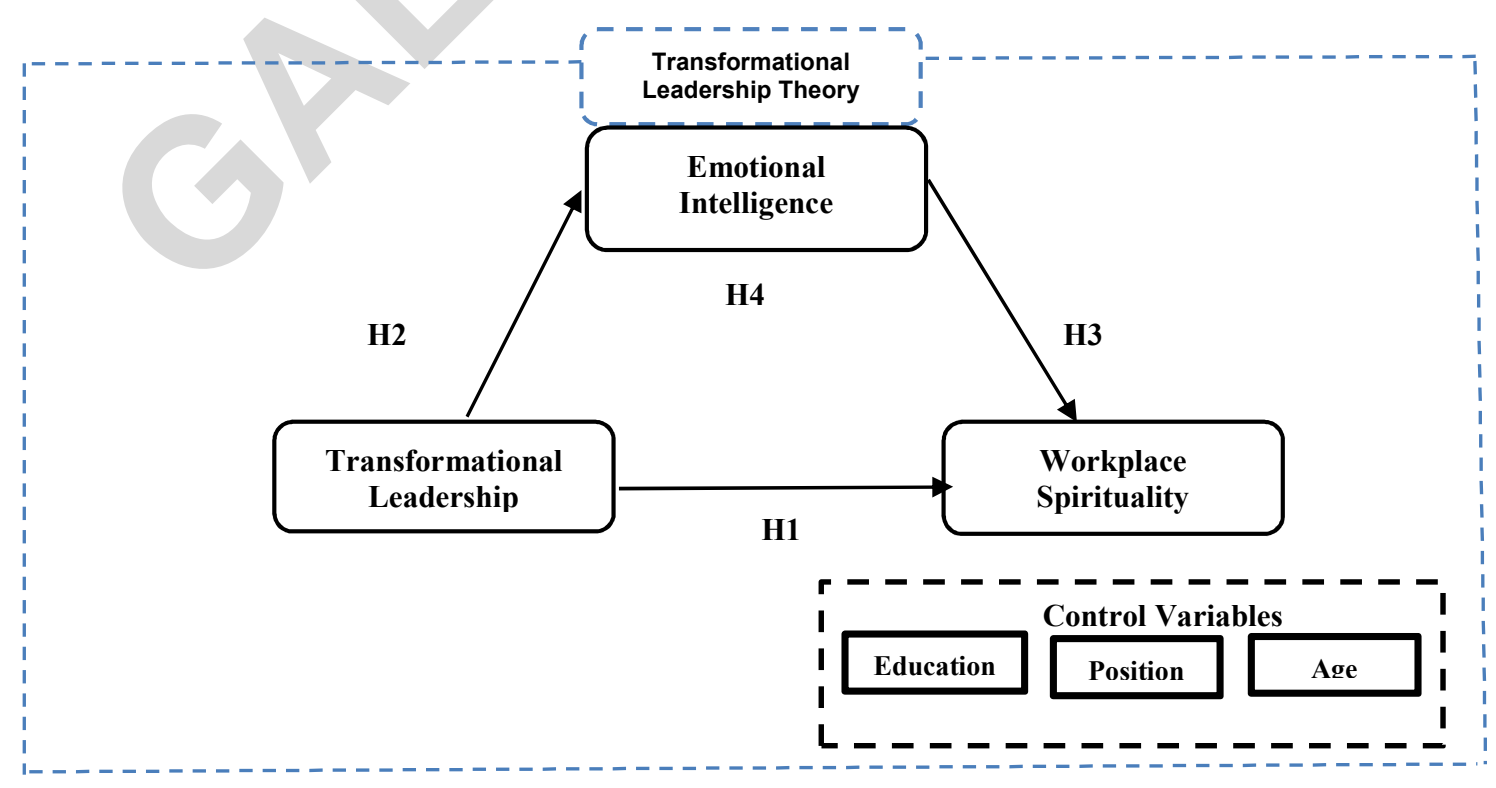

FIGURE 1. Theoretical framework 


\section{METHODOLOGY}

Keeping in view the exact idea of research, quantitative approach with a positivist paradigm is considered as the appropriate research strategy. The reason for picking a quantitative approach for this study is two-fold. It best enables the researcher to think about the effect of transformational leadership on workplace spirituality and to examine the proposed intervention through EI. Furthermore, the purpose of this study is to test the effect of transformational leadership on workplace spirituality by using associational approach for information investigation and data analysis purpose.

\section{INSTRUMENTS}

The organized survey questionnaire was utilized to accumulate the reactions. Respondents were made request rating items utilizing 5 and 7 points Likert scale that ranges from $1=$ "strongly disagree" to 7= "strongly agree". Transformational leadership was measured utilizing the Multifactor Leadership Questionnaire (MLQ) developed by Bass \&Avolio (1995) with four dimensions and 20 items. Reliability of the scale was 0.81 . EI was assessed utilizing Wong and Law (2002) 16-items scale consisting of dimensions that include (1) self-emotion appraisal, (2) others emotion appraisal, (3) understanding others emotions and (4) regulation of emotions. Scale reliability was 0.86 . Further, workplace spirituality was measured by 16 items scale developed by McKee et al. (2011). The scale comprised of 3 dimensions (1) meaningful work, (2) value alignment and (3) sense of community. The scale reliability was 0.80 .

\section{RESPONDENTS AND PROCESS}

To ensure the reliability of the instrument, a pilot study was directed. Sixty surveys were distributed in three departments to the permanent faculty members of a public sector university. Forty-five substantial reactions were acknowledged. Reliability estimations were found to be $0.91,0.87$ and 0.83 for transformational leadership, emotional intelligence, and workplace spirituality respectively. The present study was based on a sample of 252 participants (females $=103$, males $=149$ ). Among the participants $52 \%$ of individuals were working as lecturers, $26 \%$ were assistant professors, $10 \%$ were associate professors and $12 \%$ were professors. According to educational level, $76 \%$ of respondents held $\mathrm{M}$. Phil degree and $24 \%$ academicians held a doctoral degree. The age breakdown of participants is as follows: 18-25 (9\%), 26-30 (31\%), 31-40 (40\%) and $40 \&$ above (19\%). Five universities in the public sector were chosen from higher education institutions of Pakistan as the study sample. Academicians from the level of professors to lecturers were approached guaranteeing that the sample was varied and illustrative of every university. Quota sampling technique (education level i.e. Ph.D. 24\%) was employed and questionnaires were distributed among selected full-time permanent academicians employed at each university.

TABLE 1. Demographic characteristics

\begin{tabular}{lc}
\hline Demographics & Total \\
\hline Gender & $149(59)$ \\
Male & $103(41)$ \\
Female & \\
Age &
\end{tabular}




\begin{tabular}{lc}
$18-25$ & $23(9)$ \\
$26-30$ & $78(31)$ \\
$31-40$ & $103(41)$ \\
$40 \&$ above & $48(19)$ \\
Education Level & \\
M.Phil. Degree & $191(76)$ \\
Philosophy of doctor & $61(24)$ \\
Position Held & \\
Lecturer & $132(52)$ \\
Assistant Professor & $65(26)$ \\
Associate Professor & $26(10)$ \\
Professor & $29(12)$ \\
\hline
\end{tabular}

Note: Data are presented as No. (\%)

In total 290 survey questionnaires were distributed through the mail and in person. Educated assent was acquired from every one of the members and they were guaranteed of the secrecy of their responses. Points of interest in the reaction rate for every university are given in table 2. Amid information arrangement, respondents were related to their universities and were coded as universities 1-5 separately.

TABLE 2. Distribution of survey questionnaires and response rate

\begin{tabular}{cccc}
\hline Universities & $\begin{array}{c}\text { Questionnaires } \\
\text { distributed }\end{array}$ & $\begin{array}{c}\text { Questionnaires } \\
\text { received }\end{array}$ & Response Rate \\
\hline University No. 1 & 50 & 41 & $82 \%$ \\
University No. 2 & 60 & 52 & $86 \%$ \\
University No. 3 & 60 & 51 & $85 \%$ \\
University No. 4 & 60 & 52 & $86 \%$ \\
University No. 5 & 60 & 56 & $93 \%$ \\
Total & 290 & 252 & $86 \%$ \\
\hline
\end{tabular}

\section{ANALYSIS}

To analyze the data two software; SPSS (version -22) and Smart-PLS (version - 3) was used considering their respective data analytical techniques. SPSS (version - 22) was used to complete the following tasks: (1) to prepare the data for analysis (checking and treating missing values), (2) and to calculate descriptive statistics for demographic analysis. Smart-PLS was used to test the measurement and structural model by using structural equation modeling Partial least square (PLS-SEM) approach.

\section{EVALUATION OF MEASUREMENT MODEL}

The relationships between constructs and items were evaluated to determine the reliability and validity of the theoretically proposed model. While examining the appropriateness of the measurement model three conditions which are (1) factor loadings, (2) Composite Reliability (CR) and (3) Discriminant validity were investigated to ensure the reliability and validity of the model.

Convergent Validity To ensure the convergent validity initially factor loadings were examined. As recommended by Hair, Ringle and Sarstedt (2011), the minimum value for items loading is 0.70 and the value for AVE should be 0.50 or higher. Inspecting the factor loadings for each item uncovered that the factor loadings for each item range in between $0.628-0.893$ and values are positive and greater than the threshold values as reported in table 3.Convergent validity is established at the degree where numerous items that measure similar concepts are in 
agreement by examining the factor loadings, composite reliability and the values of average variance extracted (Hair et al. 2011). The items with loadings below 0.70 should be deleted from the model if the item deletion leads to escalating the values of composite reliability and average variance extracted (AVE). Following the suggested procedure after deleting the items with lower loadings all values of item loadings, CR and AVE are greater than the recommended threshold values. Table 3 depicts that the range of AVE lies between $0.506-0.714$ for all constructs. Further, figure 2 describes the constructs with the respective item loadings of the measurement models. The findings specify that all the constructs of Transformational leadership, EI and Workplace spirituality are valid measures of their respective constructs and are statistically significant at $p<0.05$.

TABLE 3. Items outer loadings and AVE for constructs

\begin{tabular}{|c|c|c|c|c|c|c|}
\hline Variables & Items & Loadings & $\begin{array}{l}\text { Composite } \\
\text { Reliability } \\
\text { (CR) }\end{array}$ & AVE & $\begin{array}{l}\mathrm{T}- \\
\text { statistics }\end{array}$ & P value \\
\hline \multicolumn{7}{|c|}{ Transformational Leadership } \\
\hline Individualized & IC2 & 0.710 & 0.829 & 0.548 & 55.324 & 0.000 \\
\hline \multirow[t]{3}{*}{ Consideration } & IC3 & 0.712 & & & & \\
\hline & IC4 & 0.761 & & & & \\
\hline & IC5 & 0.776 & & & & \\
\hline Idealized & II1 & 0.777 & 0.828 & 0.549 & 51.3 & 0.000 \\
\hline \multirow[t]{3}{*}{ influence } & II2 & 0.784 & & & & \\
\hline & II3 & 0.763 & & & & \\
\hline & II5 & 0.628 & & & & \\
\hline \multirow{4}{*}{$\begin{array}{l}\text { Inspirational } \\
\text { motivation }\end{array}$} & IM1 & 0.653 & 0.803 & 0.506 & 47.424 & 0.000 \\
\hline & IM2 & 0.759 & & & & \\
\hline & IM3 & 0.742 & & & & \\
\hline & IM5 & 0.688 & & & & \\
\hline Intellectual & IS3 & 0.720 & 0.791 & 0.559 & 34.672 & 0.000 \\
\hline \multirow[t]{2}{*}{ Stimulation } & IS4 & 0.768 & & & & \\
\hline & IS5 & 0.753 & & & & \\
\hline \multicolumn{7}{|c|}{ Workplace Spirituality } \\
\hline \multirow{4}{*}{$\begin{array}{l}\text { Meaningfulness of } \\
\text { work }\end{array}$} & MW1 & $\begin{array}{l}0.840 \\
0.802\end{array}$ & 0.894 & 0.628 & 80.36 & 0.000 \\
\hline & MW3 & 0.825 & & & & \\
\hline & MW4 & 0.719 & & & & \\
\hline & MW5 & 0.769 & & & & \\
\hline \multirow{3}{*}{$\begin{array}{l}\text { Sense of } \\
\text { Community }\end{array}$} & $\mathrm{SC} 1$ & 0.757 & 0.810 & 0.520 & 55.179 & 0.000 \\
\hline & $\mathrm{SC} 5$ & 0.704 & & & & \\
\hline & SC6 & 0.809 & & & & \\
\hline \multirow[t]{4}{*}{ Value Alignment } & VA1 & 0.744 & 0.814 & 0.524 & 58.214 & 0.000 \\
\hline & VA3 & 0.751 & & & & \\
\hline & VA4 & 0.651 & & & & \\
\hline & VA5 & 0.745 & & & & \\
\hline \multicolumn{7}{|c|}{ Emotional Intelligence } \\
\hline Self-emotional & SEA1 & 0.857 & 0.909 & 0.714 & 79.532 & 0.000 \\
\hline \multirow{3}{*}{ Appraisal } & SEA2 & 0.893 & & & & \\
\hline & SEA3 & 0.886 & & & & \\
\hline & SEA4 & 0.736 & & & & \\
\hline \multirow{4}{*}{$\begin{array}{l}\text { Others Emotion } \\
\text { appraisal (OEA) }\end{array}$} & OEA1 & 0.735 & 0.862 & 0.610 & 51.053 & 0.000 \\
\hline & OEA2 & 0.819 & & & & \\
\hline & OEA3 & 0.762 & & & & \\
\hline & OEA4 & 0.805 & & & & \\
\hline \multirow{3}{*}{$\begin{array}{l}\text { Use of emotions } \\
\text { (UOE) }\end{array}$} & UOE1 & 0.737 & 0.865 & 0.615 & 49.63 & 0.000 \\
\hline & UOE2 & 0.777 & & & & \\
\hline & UOE3 & 0.801 & & & & \\
\hline
\end{tabular}




$\begin{array}{lllllll} & \text { UOE4 } & 0.820 & & & & \\ \text { Regulation of } & \text { ROE1 } & 0.854 & 0.900 & 0.693 & 79.562 & 0.000 \\ \text { emotion (ROE) } & \text { ROE2 } & 0.849 & & & & \\ & \text { ROE3 } & 0.787 & & & & \\ & \text { ROE4 } & 0.837 & & & & \end{array}$

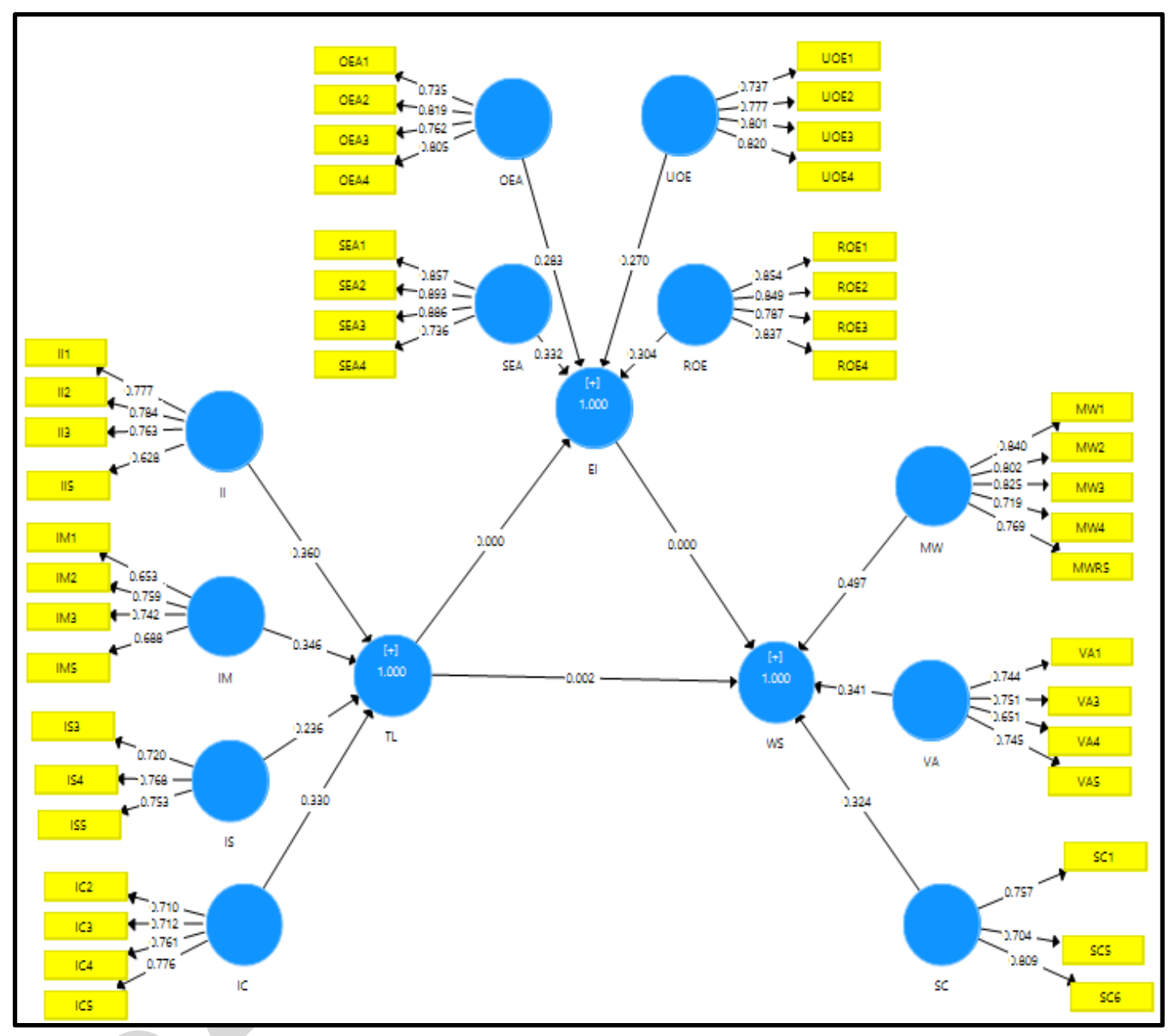

FIGURE 2. Outer model assessment

Analysis of Discriminant Validity

The purpose of discriminant validity is to ensure that the indicator has a consistent association with its respective construct while evaluating the PLS path model (Hair \& Lukas 2014). According to (Ramayah, Yeap \& Ignatius 2013), the discriminant validity is established by calculating the relationships between constructs which may have a chance to overlap with other variables. The minimum value for the average variance extracted (AVE) for all constructs must be higher than the values of the squared correlations among all other constructs (Hair \& Lukas 2014). In other words, there will be no issue of discriminant validity is the research model if the correlational values between the construct are lower than the square root of the AVE's as suggested by Fornell and Larcker (1981). Table 4 and 5 indicate the findings that establish the adequate discriminant validity of reflective and latent variables. The bold diagonal values are greater than the correlational values of other constructs thus there is no problem of discriminant validity in this study. 
TABLE 4. Discriminant validity

\begin{tabular}{|c|c|c|c|c|c|c|c|c|c|c|c|}
\hline & IC & II & IM & IS & MW & OEA & ROE & $\mathrm{SC}$ & SEA & UOE & VA \\
\hline IC & 0.740 & & & & & & & & & & \\
\hline II & 0.468 & 0.741 & & & & & & & & & \\
\hline IM & 0.533 & 0.584 & 0.712 & & & & & & & & \\
\hline IS & 0.337 & 0.428 & 0.509 & 0.747 & & & & & & & \\
\hline MW & 0.193 & 0.340 & 0.299 & 0.248 & 0.792 & & & & & & \\
\hline OEA & 0.413 & 0.407 & 0.407 & 0.307 & 0.415 & 0.781 & & & & & \\
\hline ROE & 0.391 & 0.395 & 0.456 & 0.359 & 0.447 & 0.581 & 0.832 & & & & \\
\hline $\mathrm{SC}$ & 0.302 & 0.305 & 0.340 & 0.232 & 0.535 & 0.362 & 0.372 & 0.721 & & & \\
\hline SEA & 0.330 & 0.403 & 0.422 & 0.380 & 0.468 & 0.681 & 0.609 & 0.383 & 0.845 & & \\
\hline UOE & 0.405 & 0.463 & 0.461 & 0.360 & 0.362 & 0.660 & 0.516 & 0.290 & 0.593 & 0.784 & \\
\hline VA & 0.268 & 0.340 & 0.222 & 0.147 & 0.645 & 0.367 & 0.451 & 0.632 & 0.456 & 0.304 & 0.724 \\
\hline
\end{tabular}

Note: The diagonal represents the square root of AVE, whereas the off-diagonals represent the correlation among the variables.

Legend: IC (Individualized Consideration), II (Idealized Influence),IM(Inspirational Motivation), IS(Intellectual Stimulation), $M W$ (Meaningful work), OEA (Others emotion appraisal),ROE(Regulation of emotion),SC(Sense of Community),SEA(Self emotion appraisal), UOE(Use of emotion), VA(Value Alignment).

TABLE 5. Discriminant validity

\begin{tabular}{lccc}
\hline Constructs & EI & TL & WS \\
\hline Emotional Intelligence & 0.681 & & \\
Transformational Leadership & 0.608 & 0.675 & 0.640 \\
Workplace Spirituality & 0.552 & 0.582 & 0.6 \\
\hline
\end{tabular}

Note: $\mathrm{TL}=$ Transformational leadership, WS= Workplace Spirituality, EI= Emotional Intelligence.

Heterotrait-Monotrait (HTMT) Analysis Discriminant validity is checked with the purpose to ensure reflective construct has the most grounded associations with its own indicators (e.g., in correlation with another construct) in the PLS path model (Hair \& Lukas 2014). Henseler, Ringle and Sarstedt (2015) suggested a more reliable method to establish discriminant validity by calculating HTMT ratios. The HTMT ratios required to be less than 0.85 in order to have adequate discriminant validity (Henseler et al. 2015). The table 6 reveals HTMT ratios for this study are below 0.85 full fillings the acceptable threshold values.

TABLE 6. HTMT ratios

\begin{tabular}{|c|c|c|c|c|c|c|c|c|c|c|c|}
\hline & IC & II & IM & IS & MW & OEA & ROE & $\mathrm{SC}$ & SEA & UOE & $\mathrm{VA}$ \\
\hline IC & & & & & & & & & & & \\
\hline II & 0.649 & & & & & & & & & & \\
\hline IM & 0.751 & 0.834 & & & & & & & & & \\
\hline IS & 0.503 & 0.648 & 0.793 & & & & & & & & \\
\hline MW & 0.240 & 0.426 & 0.385 & 0.341 & & & & & & & \\
\hline OEA & 0.543 & 0.540 & 0.556 & 0.445 & 0.507 & & & & & & \\
\hline ROE & 0.493 & 0.499 & 0.593 & 0.497 & 0.515 & 0.707 & & & & & \\
\hline $\mathrm{SC}$ & 0.430 & 0.428 & 0.487 & 0.346 & 0.658 & 0.488 & 0.494 & & & & \\
\hline SEA & 0.416 & 0.508 & 0.548 & 0.526 & 0.542 & 0.830 & 0.707 & 0.488 & & & \\
\hline UOE & 0.522 & 0.614 & 0.630 & 0.519 & 0.442 & 0.834 & 0.621 & 0.402 & 0.715 & & \\
\hline VA & 0.379 & 0.471 & 0.312 & 0.215 & 0.738 & 0.473 & 0.566 & 0.817 & 0.564 & 0.390 & \\
\hline
\end{tabular}

Note : IC (Individualized Consideration), II (Idealized Influence),IM(Inspirational Motivation), IS(Intellectual Stimulation), MW(Meaningful work), OEA (Others emotion appraisal),ROE(Regulation of emotion),SC(Sense of Community),SEA(Self emotion appraisal),UOE(Use of emotion),VA(Value Alignment). 


\section{EVALUATION OF INNER MODEL}

The second step in PLS-SEM is the evaluation of the inner model for observing the theorized connections among constructs. Initially, the path co-coefficients of the proposed relationships were examined followed by bootstrapping method by employing 5000 bootstrapped cases originated from 252 cases in order to obtain the statistical significant T-statistics. Further, the values of $\mathrm{R}^{2}$ for criterion variables are examined to check the variance shared by each construct. Table 7 exhibits the values of $\mathrm{R}^{2}$ for the study.

TABLE 7. Co-efficient of determination $\mathrm{R}^{2}$

\begin{tabular}{cccccc}
\hline & $\begin{array}{c}\text { Sample } \\
\text { Mean }\end{array}$ & $\begin{array}{c}\text { Standard } \\
\text { Deviation }\end{array}$ & $\mathrm{R}^{2}$ Values & T - Statistics & P- Values \\
\hline EI & 0.377 & 0.060 & 0.374 & 6.193 & 0.000 \\
WS & 0.328 & 0.062 & 0.321 & 5.181 & 0.000 \\
\hline
\end{tabular}

Note: EI (Emotional Intelligence), WS (Workplace Spirituality).

As shown in Table 6, the $R^{2}$ value for the endogenous variable, Emotional Intelligence is 0.374 , which implies that $37.4 \%$ of EI is accounted for by Transformational leadership. Further, the $\mathrm{R}^{2}$ for Workplace Spirituality is 0.321 , suggesting $32.1 \%$ of WS is shared by TL. On the whole, the proposed research model describes the moderate amount of variance shared by each endogenous construct.

\section{HYPOTHESES TESTING}

The proposed research hypothesis was tested by examining the values of path coefficients and T-statistics. As reported in table 8, all the relationships were statistically significant. The plotted values of path coefficients and $\mathrm{R}^{2}$ are exhibited in figure 3 .

TABLE 8. Path coefficients

\begin{tabular}{clccccc}
\hline Hypothesis & Relationships & $\begin{array}{c}\mathrm{P} \\
\text { Values }\end{array}$ & $\begin{array}{c}\text { Significance } \\
\text { Level }\end{array}$ & T Statistics & $\begin{array}{c}\text { Path } \\
\text { Coefficients }\end{array}$ & Decision \\
\hline $\mathrm{H}_{1}$ & TL -> WS & 0.048 & $* *$ & 1.977 & 0.153 & Supported \\
$\mathrm{H}_{2}$ & TL -> EI & 0.000 & $* * *$ & 12.306 & 0.611 & Supported \\
$\mathrm{H}_{3}$ & EI -> WS & 0.000 & $* * *$ & 6.653 & 0.460 & Supported \\
$\mathrm{H}_{4}$ & TL - $>$ EI -> WS & 0.000 & $* * *$ & 5.289 & 0.281 & Supported \\
\hline
\end{tabular}

Level of significance: $* * * \mathrm{p}<0.01, * * \mathrm{p}<0.05$

Note: $T L=$ Transformational leadership, WS=Workplace Spirituality, EI=Emotional Intelligence.

The analysis of path coefficients revealed that relationships amongst all hypothesized constructs are supported at $\mathrm{p}<0.01$, whereas the relationship of Transformational leadership on Workplace spirituality is statistically significant at $\mathrm{p}<0.05$. 


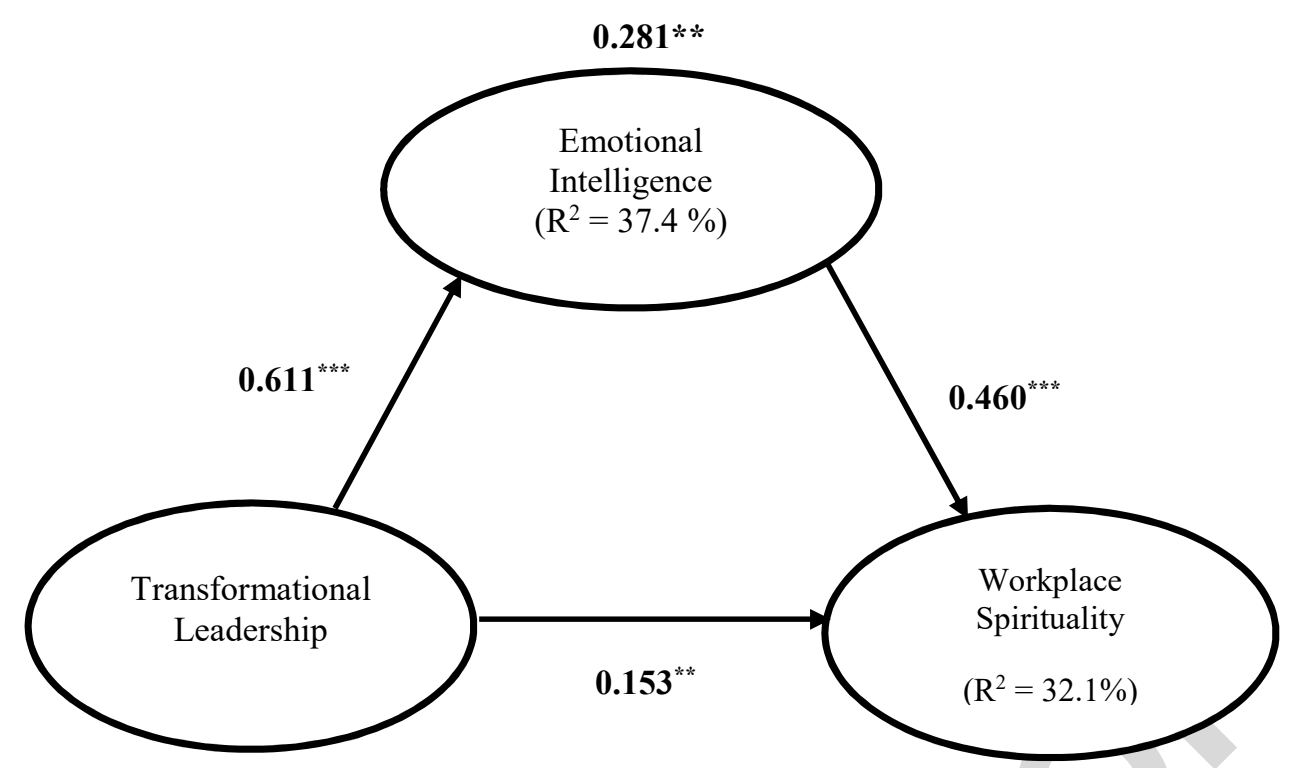

FIGURE 3. Graphical representation of inner model

Mediation Analysis Mediation characterizes a condition in which an intervening variable absorbs to some degree the outcome of an exogenous on an endogenous construct in the PLS path model (Hair \& Lukas 2014). This study adopted Preacher and Hayes (2008) procedure of testing mediation with the help of the bootstrapping method The significance of the direct effect is first checked without the presence of the mediator in the model. Thereafter, the significance of the indirect effect and associated $\mathrm{T}$ - values are checked using the path coefficients by including mediator in the model. Table $8(\mathrm{H}-4)$ depicts the results of mediation test confirming emotional intelligence as a significant mediator of the relationship between transformational leadership and workplace spirituality.

In this study level of education, the position held and age is used as control variables. Previous empirical research has shown inconsistency between these control usage and their association. These controls backed by theory relates to this study. These selected controls are used in order to find anticipated relationships between Transformational Leadership and workplace spirituality. Statistically non-significant relationships found between the selected controls and the focal variables under investigation. The values of the position held (0.052), education (0.064) and age (0.07) are non-significant on the relationship between Transformational Leadership and Workplace spirituality.

Effect Size $\left(f^{2}\right)$ and Predictive Relevance $\left(Q^{2}\right)$ Analysis $\quad$ In PLS-SEM, the values of $\mathrm{R}^{2}$ is assessed by estimating effect size $\left(f^{2}\right)$. It examines a situation when an independent variable is removed from the PLS path model. Hence by observing the extent to which the removed independent variable influences the dependent variable (Hair et al. 2016). The values of $\mathrm{f}^{2}$ can be compared by the benchmark values of $0.02,0.15$ and 0.35 which was defined as small, medium and large effects respectively (Cohen 1988). In this study, the $f^{2}$ values for TL on EI is found to be 0.596 indicating large effect. Further, the $f^{2}$ values for TL on WI is 0.22 has a small effect whereas the influence of EI on WS is found to have medium effect with a value of 0.195 . Moreover, the study investigates the predictive relevance of the PLS path model by performing the Stone-Geisser's $\left(\mathrm{Q}^{2}\right)$ test by employing the blindfolding technique in PLS-SEM (Chin 1998; Tenenhaus et al. 2005). The results of the $\mathrm{Q}^{2}$ for dependent variables are presented in table 9 which indicates that values greater than zero represent that PLS path model has a considerable amount of predictive relevance for that particular variable. 
TABLE 9. Predictive relevance $\left(Q^{2}\right)$

\begin{tabular}{lllc}
\hline Variables & SSO & SSE & $\mathrm{Q}^{2}=1-$ SSE $/$ SSO \\
\hline Emotional Intelligence (EI) & 252 & 259.061 & 0.365 \\
Workplace Spirituality (WS) & 252 & 282.845 & 0.307 \\
\hline
\end{tabular}

\section{DISCUSSION}

Scholars in higher education have somewhat neglected the complex reality of the university as an organization possessing its own structures, cultures, and practices. This implies that national policy agendas have dominated organizational research in higher education, while the views of practitioners such as institutional managers and administrators have not been sufficiently addressed (Fumasoli \&Stensaker 2013). In this study, an effort has been made to investigate the direct impact of transformational leadership on workplace spirituality with the mediating influence of emotional intelligence.

Findings of the examination endorsed that transformational leadership style is significantly related to workplace spirituality by displaying the idea of EI as a mediator. Basing on relationship and hypothesis examination all proposed speculations were found to be supported. An affirmative association was also found between EI and workplace spirituality. Accordingly, our results go in conjunction with the idea of quite a few researchers concerning the impact of leadership style on workplace spirituality (Irshad \& Hashmi 2014; Majeed et al. 2017), and the intervening impact through the lens of emotional intelligence between these variables. Adopting a transformational leadership style builds spirit at work amongst the employees and augments their inclination to perform meaningful and more significant work. Primarily within the setting of academic institutions, a sense of belongingness of academicians towards their institution is essential. Consequently, the outcomes of this study uphold the theory of transformational leadership, highlighting the value of mutual dependence in exchange for relations within the norms of reciprocation. Leaders 'do what they say they will do'. Similarly, employees would say, 'leaders practice what they preach'. 'They walk the talk'. Their actions are consistent with their words (Simons 1999). More precisely, this kind of affiliation between the departmental head and instructors influences the academicians to show extra commitment to their work and offer obligation well beyond their prescribed role, hence displaying sincere spirit while performing the job.

In addition, the relationship between emotional intelligence and workplace spirituality advances the argument that in order to make the work more meaningful and boost the spirit at work, a significant role can be played by EI. Results of this study are similar to the outcomes of the study by Moqbel, Charoensukmongkol and Bakay (2013) which affirmed that emotional intelligence has a notable relationship with workplace spirituality. The outcomes of study are in uniformity with the empirical evidence provided by earlier studies (e.g. Tischler, Biberman \& McKeage 2002; Jurkiewicz \& Giacalone 2004; Duchon \& Plowman 2005) that when individuals get sense in their work and find it more meaningful, they act in greater engagement with their work in a more coordinated way and spread total potential to work. They consequently turn out to be more imaginative as compared with workers in associations wherever the most profound sense of being and spirituality is neglected. The outcomes offered by this investigation marks a few strong contributions. Firstly the study contributes by establishing and confirming a theoretical model that has exceptionally incorporated workplace spirituality, emotional intelligence, and transformational leadership as one integrated model. The propositions by researchers that the underpinnings of workplace spirituality are addressed by transformational leadership is supported by the results of this study. Secondly, this study contributes to analyzing and validating emotional intelligence as an interceding instrument through which transformational leadership ultimately affect workplace spirituality. Findings of 
this study are consistent with earlier research leading to a positive relationship between transformational leadership and workplace spirituality. This examination has enabled in building hypothetical contention by presenting a connection and association between emotional intelligence and spirit at work. Research has been relatively silent in this area and rarely attempted to interface an association between these variables in higher educational institutions.

The current study significantly adds to the body of knowledge and provides additional insights into literature through measuring EI as mediator. The findings of this study can, therefore, help to provide a broader direction to leadership in public sector higher education in Pakistan. Therefore, the present study will not only add value and significance by exploring the mediating effect of EI in the linkage between transformational leadership and workplace spirituality but will also increase our understanding and knowledge by studying these concepts in a collectivist culture of Pakistan. A framework for enhancing workplace spirituality can be offered by promoting emotional intelligence within the educational institutions.

\section{LIMITATIONS}

This study has a few limitations that must be reflected. Due to the nature of cross-sectional data, the authors could not establish causality. For a more in-depth understanding of the causal impact amongst each variable, the longitudinal approach should be considered in future research. Another limitation is a selection of participants from a single region. The information is gathered from 252 academicians working in five public sector universities only. Hence, the findings of the study may be elaborated with extensive samples from different regions by including private universities to enhance the generalizability of the results. Additionally, the information collected by means of self-reported questionnaires, such an approach might be subject to account for biases and predispositions. Actual workplace experiences might have influenced the responses of the participants. To obtain thorough contrasts, in future studies employees from diverse cultures and background should be studied. The current study, in spite of a few of the limitations, discloses that transformational leadership and emotional intelligence offer supplementary means to enhance workplace spirituality of academicians in public sector higher education institutions. However, across diverse national settings the studies of leadership are found to be largely reliable (Avolio, Walumbwa \& Weber 2009).

\section{FUTURE RESEARCH DIRECTIONS}

Despite the research limitations, the study has successfully achieved its purpose. The main objective was to extend the leadership work by investigating associations amongst the research variables. The study has brought a wider horizon in learning by examining transformational leadership which may expand a person's spirit at work. To accomplish the research purposes this study adopted a quota sampling technique, however, to enhance the generalizability of the findings in future research random sampling technique is suggested. Future research scholars may concentrate on other intervening factors and variables such as organizational citizenship behavior, knowledge sharing behavior, organizational culture, workplace deviance, and employee engagement. To enhance the understanding of the subjective nature of the workplace spirituality construct, it would be appropriate if a qualitative study is undertaken in future research. For future studies by testing the relationship of each dimension the boundary of hypothesis could be broadened.

\section{PRACTICAL IMPLICATIONS}

Consequences of this investigation make a few useful commitments and practical contributions. This investigation offers empirical affirmation that transformational leadership 
has a direct as well as a mediating effect of EI on workplace spirituality. The outcomes of this study demonstrate that leaders in higher education institutions may be vigilant about their actions as it provides stimulus to employee's meaningfulness of work. Universities should impart training, preparing the departmental heads in exercising transformational leadership practices which may enhance educators' spirit at work. Furthermore, training programs aimed at strengthening the academicians working environment, EI, and spirit at work may be arranged on the campuses. For managers in higher educational institutions, this exclusive theoretical model offers value-added implications. To inspire academicians to display workplace spirituality behaviors, transformational leadership and emotional intelligence are important. Administrators should recognize that in order to promote workplace spirituality to a higher level, demonstration of transformational leadership style with "walk the talk" approach and emotional intelligence is essential. Walk the Talk approach exhibited by leaders empowers employees to fully involve in work and reciprocate organization by displaying spirit at work instead of concealment of determination on employment. The university administrators ought to realize that when leaders display role model behavior through idealized influence dimension of transformational leadership and "practice what they preach" with enhanced EI of leaders, it can lift the heart and engage the soul of employees. With reference to the recruitment and selection process, this study recommends that more importance should be placed on the selection of candidates with high EI. Consequently, suitable assessment instruments may be employed through the hiring process for locating prospective applicants possessing sufficient skills of emotional intelligence.

Although this is a promising study which has provided empirical evidence and observational support, further research is necessary to examine the wide-ranging nature of the connection between transformational leadership, workplace spirituality, and EI. In conclusion, the current research distinctively synthesized the theoretical concepts that may be explored in order to test the probable influence of transformational leadership and EI on workplace spirituality. The proposed research model backed by empirical support sets the platform for additional research avenues to distinguish how transformational leadership may upsurge supplementary job outcomes along with workplace spirituality.

\section{REFERENCES}

Avolio, B. \& Bass, B.M. 2002. Manual for the Multifactor Leadership Questionnaire (Form $5 X)$. Redwood City, CA: Mindgarden.

Avolio, B.J., Waldman, D.A. \& Einstein, W.O. 1988. Transformational leadership in a management game simulation: Impacting the bottom line. Group \& Organization Studies 13(1): 59-80.

Avolio, B.J., Walumbwa, F.O. \& Weber, T.J. 2009. Leadership: Current theories, research, and future directions. Annual Review of Psychology 60: 421-449.

Balwant, P.T. 2016. Transformational instructor-leadership in higher education teaching: A meta-analytic review and research agenda. Journal of Leadership Studies 9(4): 20-42.

Balwant, P.T., Stephan, U. \& Birdi, K. 2014. Practice what you preach: Instructors as transformational leaders in higher education classrooms. Academy of Management Proceedings 2014.

Bass, B.M. \& Avolio, B.J. 1993. Transformational leadership and organizational culture. Public Administration Quarterly 17(1): 112-121.

Bass, B.M. \& Avolio, B.J. 1995. The Multifactor Leadership Questionnaire-5x Short Form. Redwood: Mind Garden.

Bass, M. 1985. Leadership and Performance Beyond Expectations. New York: Free Press. 
Bass, M. \& Riggio, RE. 2006. Transformational Leadership. Mahwah, New Jersey, Lawrence Erlbaum Associates.

Breakwell, G.M. \& Tytherleigh, M.Y. 2010. University leaders and university performance in the United Kingdom: Is it 'who'leads, or 'where'they lead that matters most?" Higher Education 60(5): 491-506.

Bruckmann, S. \& Carvalho, T. 2018. Understanding change in higher education: an archetypal approach. Higher Education 76(4): 629-647.

Cavazotte, F., Moreno, V. \& Hickmann, H. 2012. Effects of leader intelligence, personality and emotional intelligence on transformational leadership and managerial performance. The Leadership Quarterly 23(3): 443-455.

Chin, W.W. 1998. The partial least squares approach to structural equation modeling. Modern Methods for Business Research 295(2): 295-336.

Cohen, J. 1988. Statistical Power Analysis for the Behavioral Sciences. $2^{\text {nd }}$ ed. Hillsdale, NJ: Lawrence Earlbaum Associates.

Crossman, J. 2011. Environmental and spiritual leadership: Tracing the synergies from an organizational perspective. Journal of Business Ethics 103(4): 553-565.

Dinh, J.E., Lord, R.G., Gardner, W.L., Meuser, J.D., Liden, R.C. \& Hu, J. 2014. Leadership theory and research in the new millennium: Current theoretical trends and changing perspectives. The Leadership Quarterly 25(1): 36-62.

Duchon, D. \& Plowman, D.A. 2005. Nurturing the spirit at work: Impact on work unit performance.The Leadership Quarterly 16(5): 807-833.

Fairholm, G.W. 1997. Capturing the Heart of Leadership: Spirituality and Community in the New American Workplace. Westport, Conn: Praeger.

Fornell, C. \& Larcker, D.F. 1981. Structural equation models with unobservable variables and measurement error: Algebra and statistics. Journal of Marketing Research 18(3): 382-388.

Fumasoli, T. \& Stensaker, B. 2013. Organizational studies in higher education: A reflection on historical themes and prospective trends. Higher Education Policy 26(4): 479-496.

Giacalone, R.A. \& Jurkiewicz, C.L. 2003. Toward a science of workplace spirituality. In Handbook of Workplace Spirituality and Organizational Performance, edited by R.A. Giacalone, \& C.L. Jurkiewicz, 3-28. New York, NY: M.E. Sharpe.

Goleman, D. 1998. Working with Emotional Intelligence. New York: Bantam Books.

Hair, J., Hult, T., Ringle, C. \& Sarstedt, M. 2016. A Primer on Partial Least Squares Structural Equation Modeling (PLS-SEM). Thousand Oaks: Sage Publications.

Hair, J.F., Ringle, C.M. \& Sarstedt, M. 2011. PLS-SEM: Indeed a silver bullet. Journal of Marketing Theory and Practice 19(2): 139-152.

Hair Jr, J.F. \& Lukas, B. 2014. Marketing Research. North Ryde, N.S.W. : McGraw-Hill Education Australia.

Henseler, J., Ringle, C.M. \& Sarstedt, M. 2015. A new criterion for assessing discriminant validity in variance-based structural equation modeling. Journal of the Academy of Marketing Science 43(1): 115-135.

Irshad, R. \& Hashmi, M.S. 2014. How transformational leadership is related to organizational citizenship behavior? The mediating role of emotional intelligence. Pakistan Journal of Commerce \& Social Sciences 8(2): 413-425.

Ishak, N.M., Iskandar, I.P. \&Ramli, R. 2010. Emotional intelligence of Malaysian teachers: A comparative study on teachers in daily and residential schools. Procedia-Social and Behavioral Sciences 9: 604-612.

Jamshed, S. \& Majeed, N. 2019. Relationship between team culture and team performance through lens of knowledge sharing and team emotional intelligence. Journal of Knowledge Management 23(1): 90-109. 
Jamshed, S., Nor, M.N.M \& Bakar, R.A. 2017. Enhancing team effectiveness through leader emotional intelligence and knowledge sharing: structural equation modeling approach. International Online Journal of Educational Leadership 1(1): 34-59.

Joelle, M. \& Coelho, A.M. 2017. The impact of spirituality at work on workers' attitudes and individual performance. The International Journal of Human Resource Management 30(7): 1-25.

Jurkiewicz, C.L. \& Giacalone, R.A. 2004. A values framework for measuring the impact of workplace spirituality on organizational performance. Journal of Business Ethics 49(2): 129-142.

Koeslag-Kreunen, M.G., Van der Klink, M.R., Van den Bossche, P. \& Gijselaers, W.H. 2018. Leadership for team learning: The case of university teacher teams. Higher Education 75(2): 191-207.

Majeed, N. 2018. Which spirituality at the workplace? Is corporate spirituality the answer. Kuwait Chapter of the Arabian Journal of Business and Management Review 7(1): 49-60.

Majeed, N., Nor, M.N.M. \& Mustamil, N.M. 2017. Exploring relationship between transformational leadership and organizational citizenship behaviors through lens of workplace spirituality. International Online Journal of Educational Leadership 1(1): 533.

Majeed, N., Ramayah, T., Mustamil, N., Nazri, M. \& Jamshed, S. 2017. Transformational leadership and organizational citizenship behavior: Modeling emotional intelligence as mediator. Management \& Marketing 12(4): 571-590.

McKee, M.C., Driscoll, C., Kelloway, E.K. \& Kelley, E. 2011. Exploring linkages among transformational leadership, workplace spirituality and well-being in health care workers. Journal of Management, Spirituality \& Religion 8(3): 233-255.

Middlehurst, R. 2008. Not enough science or not enough learning? Exploring the gaps between leadership theory and practice. Higher Education Quarterly 62(4): 322-339.

Mitroff, I.I. \& Denton, E.A. 1999. A Spiritual Audit of Corporate America: A Hard Look at Spirituality, Religion, and Values in the Workplace. San Fancisco: Jossey-Bass.

Moqbel, M., Charoensukmongkolm, P. \& Bakay, A. 2013. Are US academics and professionals ready for IFRS? An explanation using technology acceptance model and theory of planned behavior. Journal of International Business Research 12(2): 47-60.

Mousa, M. \& Alas, R. 2016. Workplace spirituality and organizational commitment: A study on the public schools teachers in Menoufia (Egypt). African Journal of Business Management 10(10): 247-255.

Pirkola, H., Rantakokko, P. \& Suhonen, M. 2016. Workplace spirituality in health care: An integrated review of the literature. Journal of Nursing Management 24(7): 859-868.

Porshariati, M., Dousti, M. \& Moosavi, S. 2014. Study of the relationship between workplace spirituality and organizational citizenship behavior in physical education teachers in Tehran City. International Journal of Sport Studies 4(4): 386-393.

Preacher, K.J. \& Hayes, A.F. 2008. Asymptotic and resampling strategies for assessing and comparing indirect effects in multiple mediator models. Behavior Research Methods 40(3): 879-891.

Ralph, M. \& Stubbs, W. 2014. Integrating environmental sustainability into universities. Higher Education 67(1): 71-90.

Ramayah, T., Yeap, J.A. \& Ignatius, J. 2013. An empirical inquiry on knowledge sharing among academicians in higher learning institutions. Minerva 51(2): 131-154.

Ramlall, S. 2004. A review of employee motivation theories and their implications for employee retention within organizations. Journal of American Academy of Business 5(1/2): 52-63. 
Roof, R.A. 2015. The association of individual spirituality on employee engagement: The spirit at work. Journal of Business Ethics 130(3): 585-599.

Salovey, P. \& Mayer, J.D. 1990. Emotional intelligence. Imagination, Cognition and Personality 9(3): 185-211.

Simons, T.L. 1999. Behavioral integrity as a critical ingredient for transformational leadership. Journal of Organizational Change Management 12(2): 89-104.

Tenenhaus, M., Vinzi, V.E., Chatelin, Y.-M. \& Lauro, C. 2005. PLS path modeling. Computational Statistics \& Data Analysis 48(1): 159-205.

Tischler, L., Biberman, J. \& McKeage, R. 2002. "Linking emotional intelligence, spirituality and workplace performance: Definitions, models and ideas for research. Journal of Managerial Psychology 17(3): 203-218.

Top, M., Akdere, M. \& Tarcan. M. 2015. Examining transformational leadership, job satisfaction, organizational commitment and organizational trust in Turkish hospitals: Public servants versus private sector employees. The International Journal of Human Resource Management 26(9): 1259-1282.

Weisinger, H. \& Cali, R.L.L. 2000. Emotional Intelligence at Work: The Untapped Edge for Success. San Francisco: Jossey-Bass.

Wong, C.-S. \& Law, K.S. 2002. The effects of leader and follower emotional intelligence on performance and attitude: An exploratory study. The Leadership Quarterly 13(3): 243274.

Woods, C. 2010. Employee wellbeing in the higher education workplace: A role for emotion scholarship. Higher Education 60(2): 171-185.

Nauman Majeed (corresponding author)

Department of Business Strategy and Policy

Faculty of Business and Accountancy

University of Malaya

50603 Kuala Lumpur, MALAYSIA.

E-Mail:majeed.nauman@gmail.com; naumanm@um.edu.my

Samia Jamshed

Faculty of Business and Management Sciences

Superior University

54590 Lahore, PAKISTAN.

E-Mail: samiajamshed@gmail.com ; samia.jamshed@superior.edu.pk

Mohammad Nazri

Department of Business Strategy and Policy

Faculty of Business and Accountancy

University of Malaya

50603 Kuala Lumpur, MALAYSIA.

E-Mail: nazrry@um.edu.my

Norizah Mohd Mustamil

Department of Business Strategy and Policy

Faculty of Business and Accountancy

University of Malaya

50603 Kuala Lumpur, MALAYSIA.

E-Mail: norizahmm@um.edu.my 